\title{
Cancer incidence and mortality in the Swedish polyurethane foam manufacturing industry
}

Lars Hagmar, Hans Welinder, Zoli Mikoczy

\begin{abstract}
Toluene diisocyanate (TDI) and methylene diphenyldiisocyanate (MDI) are used in large quantities in the polyurethane foam manufacturing industry. Both substances are mutagenic and at least TDI is carcinogenic to animals, but the occupational hazard with respect to cancer is not known. Cancer incidence and mortality patterns were therefore investigated in a cohort of 4154 workers from nine Swedish plants manufacturing polyurethane foam, employed for at least one year. Each workplace and job task in the nine plants was categorically assessed for each calendar year by an experienced occupational hygienist, for "no exposure", "low or intermittent exposure", or "apparent exposure" to TDI and MDI. The observed deficit for all cause mortality (standardised mortality ratio (SMR) $0 \cdot 78$, $(95 \%$ confidence interval $(95 \% \mathrm{CI})$ $0.66-0.93$ ) became smaller (SMR 0.92) excluding the first 10 years since the start of exposure and was ascribed to a healthy worker effect. No increased risk for death from bronchial obstructive diseases was found. An almost statistically significant deficit occurred for all malignant neoplasms (standardised incidence ratio (SIR) $0.81,95 \%$ CI 0.63-1.02); slight (not significant) increased risks were found for rectal cancer (SIR 1.66) and nonHodgkin's lymphoma (SIR 1.53). The SIR for non-Hodgkin's lymphoma increased to 2.80 $(95 \%$ CI $0 \cdot 76-7 \cdot 16)$ when the first 10 years since first exposure were excluded from the observation period. The corresponding figure for rectal cancer was 1.92 (95\% CI $0.52-4 \cdot 92)$. Further restricting the analysis to those who had experienced an apparent exposure to TDI or MDI increased the SIR for both rectal cancer $(3 \cdot 19,95 \%$ CI $0 \cdot 66-9 \cdot 33)$, and non-
\end{abstract}

Department of Occupational and Environmental Medicine, University Hospital, S-221 85 Lund, Sweden

L Hagmar, H Welinder, Z Mikoczy
Hodgkin's lymphoma (3.03, 95\% CI 0.37-10.9). These estimates were based, however, on few incident cases. As the cohort is still young and little time has elapsed since the start of exposure, future follow ups will enable a more conclusive evaluation.

(British fournal of Industrial Medicine 1993;50:537-543)

During the past decades the industrial use of isocyanates has rapidly increased in the industrialised parts of the world. The annual world production of aromatic isocyanates as toluene diisocyanate (TDI) and methylene diphenyldiisocyanate (MDI) is currently approaching one million tonnes each. ${ }^{1}$ The main use of these compounds is in the polyurethane foam manufacturing industry.

Commercial grades of TDI and MDI are mutagenic in bacterial test systems after metabolic activation..$^{23}$ Oral administration of commercial grade TDI caused increased incidence of tumours among male (fibrosarcomas, pancreatic acinar cell adenomas) and female (pancreatic acinar cell adenomas, neoplastic nodules of the liver, and mammary gland fibroadenomas) rats and female mice (haemangiosarcomas and hepatocellular adenomas). ${ }^{4}$ Inhalation of up to $1 \mathrm{mg} / \mathrm{m}^{3}$ commercial grade TDI did not, however, cause tumours in rats or mice. ${ }^{5}$ The exposures used in that study have been criticised because they did not reach a maximum tolerated dose. ${ }^{4}$ Commercial grade TDI has been classified as carcinogenic in animals ${ }^{36}$ and a potential occupational carcinogen. ${ }^{7}$ To our knowledge, no data have been published on the testing of MDI for carcinogenicity.

Isomers of TDI and MDI are converted to the corresponding isomers of aromatic amines on contact with water and 2,4-TDA (2,4 toluenediamine) and 2,6-TDA have been detected in urine and plasma from subjects experimentally exposed to $\mathrm{TDI}^{8}$ as well as from employees in the polyurethane foam industry. 4,4-MDA has been detected in blood and urine from welders exposed to pyrolysed MDI based polyurethane (unpublished results). The carcinogenic and mutagenic effect of inhaled or dermally absorbed isocyanates may be due to endogenous formation of these aromatic amines. 
Both 2,4-TDA and 4,4-methylenedianiline (4,4MDA) are established animal carcinogens. ${ }^{6}$

Despite the positive cancer studies in animals, no epidemiological study on cancer risks for humans occupationally exposed to isocyanates has been published. The aim of our present study was to investigate the risk of cancer among employees in the Swedish polyurethane foam manufacturing industry who were exposed to commercial grades of TDI and MDI.

The main health concern with occupational exposure to isocyanates has been their asthma inducing and sensitising properties, ${ }^{9}$ and a loss of pulmonary function related to long term low level exposure to TDI has been shown. ${ }^{10}$ Whether these biological effects of occupational exposure to TDI may also cause an excess of deaths in obstructive lung diseases is not known, however. The design of our study made such an evaluation possible.

\section{Subjects and methods}

THE PLANTS

Eleven Swedish plants manufacturing polyurethane foam in which TDI or MDI had been used were contacted. Representatives from all plants agreed to participate in the study, but two of the plants were not eligible due to the poor quality of their personnel records. The remaining nine plants were included in the study. Three of these plants have produced flexible foam blocks (block foaming) mainly for the furniture industry, and the remaining six plants have manufactured dead cast moulding materials, mostly for the car industry (table 1 ). The start of manufacture of polyurethane foam varied between 1958 and 1974 for the different plants (table 2).

The block foaming comprised foaming and expanding of low density materials $\left(<50 \mathrm{~kg} / \mathrm{m}^{3}\right)$ for sale and for further manufacturing within the plants. At present the blocks are stored in a separate room for at least three days before further handling. Thus, the exposure for most workers now is low except for those directly involved in the foaming process. Earlier the blocks were stored within the production premises and manufactured after 24 hours.

Dead cast moulding and further handling of the

Table 1 Exposure and monitoring characteristics of the nine polyurethane foam manufacturing plants

\begin{tabular}{|c|c|c|c|c|c|c|c|}
\hline \multirow[b]{2}{*}{ Plant } & \multirow{2}{*}{$\begin{array}{l}\text { Production } \\
\text { method }^{\star}\end{array}$} & \multirow{2}{*}{$\begin{array}{l}\text { TDI exposure } \\
\text { period }\end{array}$} & \multirow{2}{*}{$\begin{array}{l}\text { MDI exposure } \\
\text { period }\end{array}$} & \multirow{2}{*}{$\begin{array}{l}\text { First year } \\
\text { of monitoring }\end{array}$} & \multirow{2}{*}{$\begin{array}{l}\text { Number of } \\
\text { monitored dayst }\end{array}$} & \multicolumn{2}{|c|}{ Highest exposure $\left(\mathrm{mg} / \mathrm{m}^{3}\right) \ddagger$} \\
\hline & & & & & & TDIS & $M D I$ \\
\hline $\begin{array}{l}\text { A } \\
B \\
C \\
D \\
E \\
F \\
G \\
H \\
I\end{array}$ & $\begin{array}{l}\text { B } \\
B \\
A \\
A+B \\
A+B \\
B \\
B \\
A+B \\
B\end{array}$ & $\begin{array}{l}1959-73 \\
1969- \\
1973-90 \\
1958- \\
1962- \\
1972- \\
1981-83 \\
1958-74 \\
1977-87\end{array}$ & $\begin{array}{l}1968- \\
1969- \\
1982-90 \\
? \\
1972- \\
1970- \\
1964- \\
1966-\end{array}$ & $\begin{array}{l}1973 \\
1978 \\
1974 \\
1971 \\
1965 \\
1975 \\
1973 \\
1967 \\
1974\end{array}$ & $\begin{array}{r}18 \\
7 \\
16 \\
24 \\
17 \\
11 \\
18 \\
10 \\
15\end{array}$ & $\begin{array}{l}0.11 \\
0.026 \\
0.1 \\
3.0 \\
0.57 \\
0.026 \\
0.11 \\
0.48 \\
0.68\end{array}$ & $\begin{aligned} & 0.16 \\
< & 0.026 \\
< & 0.005 \\
& 0.01 \\
& \\
< & 0.007 \\
& 0.11 \\
< & 0.01 \\
& 0.11\end{aligned}$ \\
\hline
\end{tabular}

*A block foaming, $B$ dead cast moulding.

tNumber of days when air monitoring for isocyanates was performed.

¥Measured by personal monitoring.

\$The present Swedish occupational exposure limit value for an eight hour work day is $0.04 \mathrm{mg} / \mathrm{m}^{3}$

The present Swedish occupational exposure limit value for an eight hour work day is $0.05 \mathrm{mg} / \mathrm{m}^{3}$.

Table 2 Characteristics of the nine subcohorts of workers employed for at least one year in the polyurethane foam manufacturing industry

\begin{tabular}{llllrr}
\hline Plant & $\begin{array}{l}\text { Start of polyurethene } \\
\text { foaming }\end{array}$ & $\begin{array}{l}\text { Complete } \\
\text { cohort }\end{array}$ & $\begin{array}{l}\text { Observation } \\
\text { period }\end{array}$ & $\begin{array}{l}\text { Cohort } \\
\text { size }\end{array}$ & $\begin{array}{l}\text { Person-years } \\
\text { under obseriation }\end{array}$ \\
\hline A & 1959 & 1963 & $1963-87$ & 264 & 3840 \\
B & 1969 & 1973 & $1973-87$ & 70 & 910 \\
C & 1973 & 1975 & $1975-87$ & 144 & 1012 \\
D & 1958 & 1972 & $1972-87$ & 390 & 357 \\
E & 1962 & 1966 & $1966-87$ & 405 & 4589 \\
F & 1972 & 1974 & $1974-87$ & 373 & 2352 \\
H & 1970 & 1950 & $1970-87$ & 953 & 6340 \\
I & 1958 & 1971 & $1959-87$ & 1040 & 9781 \\
\hline
\end{tabular}


products (cell crushing, trimming, and assembling) have usually been located within the same premises. Thus workers other than moulders have been directly exposed to the isocyanates.

\section{CHEMICAL EXPOSURE}

Airborne exposure to isocyanates was measured on six to 18 occasions (mean nine) at each plant. Sampling was performed on a total of seven to 24 (mean 15) days (table 1). The first measurement was in 1965. The time weighted average concentrations of TDI were normally below $100 \mu \mathrm{g} / \mathrm{m}^{3}$ and are presently below $20 \mu \mathrm{g} / \mathrm{m}^{3}$. The corresponding values for MDI were below $10 \mu \mathrm{g} / \mathrm{m}^{3}$. Much higher values (TDI up to $3 \mathrm{mg} / \mathrm{m}^{3}$; MDI up to 0.35 $\mathrm{mg} / \mathrm{m}^{3}$ ) have, however, repeatedly been measured. Also, there are reports of many accidental exposures to isocyanates due to spills and leakages.

Chemical exposure has not been restricted to isocyanates but also included (1) expanding agents such as freon 11 and freon 113 , (2) mould lubricants such as silicone oil and wax, (3) amine accelerators such as bis (2-dimethylaminoethyl) ether, dimethylcyclohexylamine, dimethylethanolamine, ethanolamine, methylenebis-o-chloroaniline (MOCA), N-methylmorpholine, triethanolamine, triethylamine, and triethylenediamine (DABCO), and (4) organic solvents such as petroleum, methylene chloride, methylethyl ketone, styrene, tetrachloroethylene, trichloroethane, toluene, and white spirit. These other chemicals have rarely been monitored.

A more detailed description of occupational exposure to isocyanates and other chemicals in the Swedish polyurethane foam manufacturing industry will be published elsewhere.

\section{EXPOSURE ESTIMATES}

Each workplace and work task in the nine plants were categorically assessed for each calendar year by an experienced occupational hygienist for "no exposure", "low or intermittent exposure", or

Table 3 Vital status as of 31 December 1987 in the cohort of 4154 workers employed for at least one year in the polyurethane foam manufacturing industry

\begin{tabular}{lcrrr}
\hline Plant & $\begin{array}{l}\text { Living in } \\
\text { Sweden }\end{array}$ & Dead & Emigrated & Total \\
\hline A & 236 & 17 & 11 & 264 \\
B & 67 & 3 & 0 & 70 \\
C & 141 & 2 & 1 & 144 \\
D & 360 & 20 & 10 & 390 \\
E & 380 & 19 & 6 & 405 \\
F & 361 & 9 & 3 & 373 \\
G & 923 & 19 & 11 & 953 \\
H & 943 & 84 & 13 & 1040 \\
I & 496 & 14 & 5 & 515 \\
All & 3907 & 187 & 60 & 4154 \\
\hline
\end{tabular}

"apparent exposure" to TDI or MDI. The classification apparent exposure denotes direct exposure at the foaming or moulding processes or work in the same premises. The classification low or intermittent exposure denotes handling of cured materials in premises situated close by those used for foaming or moulding, or only intermittent exposures.

\section{COHORT}

Name, date of birth, address, date of start and end of employment, and workplace or job task were obtained through the company records. Workers who had left employment or died before the year the company registers were complete were not included in the cohort. Seventy subjects whose personal identification code could not be retrieved and 686 subjects with missing data on start or end of employment had to be excluded. The remaining 6426 workers had been employed for at least one day before 1987 . The final cohort was restricted to those 4154 workers employed for at least one year before 1987. Information on workplace or job task was available for all but 139 of these subjects. Vital status was determined as of 31 December 1987 (table 3). None was lost to follow up.

The observation periods differed between the plants, due to which year the foaming started and the year from which the company records were considered to be complete and valid (table 2). The average duration of employment in the cohort was 6.5 years, the average first year of exposure was 1976 , and the average follow up was 10.6 years. Table 4 shows the distribution of person-years by age group and calendar year in the cohort.

INFORMATION ON CAUSES OF DEATH AND TUMOURS Information on cause of death (1959-87) was obtained from Statistics Sweden. The death certificates were coded according to the International Classification of Diseases (ICD). All codes were transformed to the 8 th revision of the ICD. Information on tumours (coded according to the ICD-7th revision) diagnosed from 1959 to 1987, was obtained from the National Swedish Tumour Register.

Table 4 Person-years under observation in the cohort of 4154 workers employed for at least one year in one of the nine polyurethane foaming plants

\begin{tabular}{lrrrrr}
\hline & \multicolumn{2}{l}{ Age $(y)$} & & \\
\cline { 2 - 4 } Calendar period & $<30$ & $30-59$ & $60-79$ & & Total \\
\hline $1958-70$ & 754 & 1382 & 187 & 2323 \\
$1971-80$ & 5099 & 7892 & 1242 & 14233 \\
$1981-87$ & 6807 & 11618 & 2194 & 20619 \\
Total & 12660 & 20892 & 3623 & 37175 \\
\hline
\end{tabular}


RISK ESTIMATES

Expected mortality for the period 1959-87 was calculated with calendar year, cause, sex, and five year age group specific death rates for Sweden. These rates were obtained from Statistics Sweden. Date of death, emigration, or a person's 80th birthday were used as individual endpoints, whichever occurred first.

Similarly, yearly incidence rates for cancer in the period 1959-87 were obtained from the National Swedish Tumour Register. Date of death, tumour diagnosis, emigration, or a person's 80th birthday were used as individual endpoints, whichever occurred first.

Cause-specific standardised mortality and incidence ratios (SMRs and SIRs) and 95\% confidence intervals (95\% CIs) were calculated according to the Poisson distribution, or to the $\chi^{2}$ distribution if the expected values were greater than 10 .

The person-years under observation after the point in time when a subject had been apparently exposed to TDI or MDI for a year were used for calculating the SIRs for this exposure category. The same principle was used for low or intermittent exposure, with the exception that if a subject had previously been apparently exposed for at least a year, the person-years were assigned to that exposure category instead. Moreover, if an apparent exposure period followed a low or intermittent exposure period, person-years under observation were only assigned to the second category until one year after the start of the apparent exposure period. The remaining person-years were assigned to the non-exposure category. As only few person-years were assigned to the low or intermittent exposure category (3620 v 19766 for the apparent exposure category), it was excluded from further analysis.

Significance was indicated when the $95 \%$ CI for an SMR or SIR did not include a value of 1 . All tests used were two tailed.

\section{Results}

MORTALITY

Table 5 presents the cause specific mortality. A statistically significant deficit for all cause mortality was evident (130 deaths observed $v \quad 165.9$ expected, SMR 0.78, 95\% CI 0.66-0.93). Both cardiovascular diseases $(S M R=0.82)$ and malignant tumours (SMR $=0.77$ ) contributed to this deficit. Only two deaths from bronchial obstructive diseases were found as compared with 3.3 expected. For deaths in accidents, poisonings and violence there was, however, a slight, but not significant, excess $(\mathrm{SMR}=1 \cdot 12,95 \%$ CI $0 \cdot 75-1 \cdot 63)$. The relative risks for mortality were lowest for the first 10 years since first exposure, and somewhat higher when more time had passed.

\section{INCIDENCE OF CANCER}

Table 6 presents the site specific incidence of cancer. There was an almost statistically significant deficit for all malignant neoplasms (72 observed $v$ 89.4 expected, SIR 0.81, 95\% CI 0.63-1.02). Slight, and not significant, excesses were found for rectal cancer (SIR 1.66), and non-Hodgkin's lymphoma (SIR 1.53).

The SIR for rectal cancer was 1.30 during the first 10 years since the start of exposure but 1.92 during the further observation period (table 7). This discrepancy was even more obvious for lymphomas and myelomas. All six incident cases were diagnosed 11 to 21 years after the start of exposure. The SIR for non-Hodgkin's lymphoma, when the first 10 years since first exposure were excluded from the observation period, was $2 \cdot 80$. By contrast, years from first exposure did not affect the incidence of all malignant neoplasms or incidence of lung cancer.

When the observation periods were separated with regard to exposure to TDI or MDI during the preceding job period, this hardly affected the SIRs

Table 5 Mortality 1958-87 in 4154 subjects employed for at least one year by time since first exposure

\begin{tabular}{|c|c|c|c|c|c|c|c|c|c|c|}
\hline \multirow[b]{3}{*}{ Cause of death } & \multirow[b]{3}{*}{$I C D-8$} & \multicolumn{9}{|c|}{ Years since first exposure } \\
\hline & & \multicolumn{3}{|c|}{$1-10$} & \multicolumn{3}{|c|}{$>10$} & \multicolumn{3}{|c|}{ Total } \\
\hline & & $O$ & $E$ & $\operatorname{SMR}(95 \% C I)$ & $O$ & $E$ & $S M R(95 \% C I)$ & $O$ & $E$ & $S M R(95 \% C I)$ \\
\hline Malignant tumours & $140-209$ & 11 & $18 \cdot 2$ & $0.61(0.30-1.08)$ & 22 & $24 \cdot 8$ & $0.89(0.57-1.36)$ & 33 & $43 \cdot 0$ & $0.77(0.53-1.09)$ \\
\hline $\begin{array}{l}\text { Cardiovascular } \\
\text { diseases }\end{array}$ & $390-458$ & 17 & $24 \cdot 6$ & $0.69(0.41-1.12)$ & 41 & $45 \cdot 5$ & $0.90(0.65-1 \cdot 23)$ & 58 & $70 \cdot 1$ & $0.82(0.63-1.07)$ \\
\hline Respiratory diseases & $460-519$ & 0 & $2 \cdot 6$ & $0.00(0.00-1.41)$ & 4 & $4 \cdot 7$ & $0.85(0.23-2 \cdot 18)$ & 4 & $7 \cdot 3$ & $0.55(0.15-1.41)$ \\
\hline $\begin{array}{l}\text { Asthma, } \\
\text { bronchitis, } \\
\text { emphysema }\end{array}$ & $490-493$ & 0 & $1 \cdot 3$ & $0.00(0.00-2.84)$ & 2 & $2 \cdot 0$ & $1 \cdot 02(0 \cdot 12-3 \cdot 67)$ & 2 & $3 \cdot 3$ & $0.61(0.07-2 \cdot 21)$ \\
\hline $\begin{array}{l}\text { Accidents, } \\
\text { poisonings, and } \\
\text { violence }\end{array}$ & $800-999$ & 15 & $16 \cdot 1$ & $0.93(0.52-1.54)$ & 13 & $9 \cdot 0$ & $1.45(0.77-2.48)$ & 28 & $25 \cdot 1$ & $1 \cdot 12(0.75-1 \cdot 63)$ \\
\hline All causes & 000-999 & 44 & $72 \cdot 7$ & $0.61(0.44-0.82)$ & 86 & $93 \cdot 3$ & $0.92(0.74-1.14)$ & 130 & 165.9 & $0.78(0.66-0.93)$ \\
\hline
\end{tabular}

$\mathrm{O}=$ Observed No of deaths; $\mathrm{E}=$ expected No of deaths; $\mathrm{SMR}=$ standardised mortality ratio; $95 \% \mathrm{CI}=95 \%$ confidence interval. 
Table 6 Cancer incidence 1959-87 in 4154 subjects employed for at least one year

\begin{tabular}{|c|c|c|c|c|c|}
\hline Tumour site & $I C D-7$ & $O$ & $E$ & $S I R$ & $(95 \% C I)$ \\
\hline Colon & & 4 & & 0.71 & 83) \\
\hline Rectum & & 6 & & .66 & $51-3 \cdot 61)$ \\
\hline $\begin{array}{l}\text { Liver, extrahepatic } \\
\text { gall ducts }\end{array}$ & & 2 & & & $2-3.58)$ \\
\hline Lung & $162-164$ & 4 & $7 \cdot 9$ & 0.51 & $(0 \cdot 14-1 \cdot 30)$ \\
\hline Breast & 170 & 5 & & 0.53 & $(0 \cdot 17-1 \cdot 23)$ \\
\hline Female genital organs & $171-176$ & 6 & & 0.87 & $(0 \cdot 32-1 \cdot 89)$ \\
\hline Prostate & 177 & 7 & $8 \cdot$ & 0.80 & $(0.32-1 \cdot 65)$ \\
\hline Urinary bladder, ureter & 181 & 4 & 4 . & 0.89 & $(0 \cdot 24-2 \cdot 28)$ \\
\hline Melanoma & 19 & 3 & & 0.76 & $(0 \cdot 16-2 \cdot 21)$ \\
\hline $\begin{array}{l}\text { Brain and nervous } \\
\text { system }\end{array}$ & 193 & 2 & $4 \cdot 1$ & 0.49 & $(0.06-1 \cdot 76)$ \\
\hline $\begin{array}{l}\text { Haematopoietic, } \\
\text { lymphatic }\end{array}$ & $200-207$ & 9 & $7 \cdot 1$ & $1 \cdot 27$ & $(0 \cdot 58-2 \cdot 41)$ \\
\hline $\begin{array}{l}\text { Lymphomas, } \\
\text { myelomas }\end{array}$ & $200-203$ & 6 & $4 \cdot 7$ & $1 \cdot 27$ & $(0 \cdot 47-2 \cdot 76)$ \\
\hline $\begin{array}{l}\text { Non-Hodgkin's } \\
\text { lymphoma }\end{array}$ & 200,202 & 4 & $2 \cdot 6$ & $1 \cdot 53$ & $(0.42-3.91)$ \\
\hline $\begin{array}{l}\text { Hodgkin's } \\
\text { lymphoma }\end{array}$ & 201 & 1 & $1 \cdot 0$ & 0.99 & $(0.03-5 \cdot 52)$ \\
\hline $\begin{array}{l}\text { Multiple myeloma } \\
\text { Leukaemia }\end{array}$ & $\begin{array}{l}203 \\
204-207\end{array}$ & $\begin{array}{l}1 \\
3\end{array}$ & $\begin{array}{l}1 \cdot 1 \\
2 \cdot 4\end{array}$ & $\begin{array}{l}0.91 \\
1 \cdot 27\end{array}$ & $\begin{array}{l}(0.02-5.07) \\
(0.26-3.70)\end{array}$ \\
\hline All & $140-209$ & 72 & 89.4 & 0.81 & $(0.63-1.02)$ \\
\hline
\end{tabular}

SIR $=$ Standardised incidence ratio.

for all malignant neoplasms $(0.79 v 0.85$, table 8). By contrast, the SIR for rectal cancer associated with no exposure was 0.70 , but 2.73 (95\% CI 0.89 $6 \cdot 38$ ) associated with apparent exposure. A much weaker tendency in the same direction was seen for non-Hodgkin's lymphoma (SIR $1.01 v 1.45$ ). When a minimum latency period of 10 years for job tasks with apparent exposure to TDI or MDI was applied the SIRs increased further for both rectal cancer $(3 \cdot 19,95 \%$ CI $0 \cdot 66-9 \cdot 33)$, and nonHodgkin's lymphoma $(3.03,95 \%$ CI $0.37-10 \cdot 9)$. These estimates were, however, based on few incident cases (three and two, respectively).

\section{Discussion}

The main result of the study was the non-significant risk excess for rectal cancer and nonHodgkin's lymphoma that increased after a 10 year induction latency period of apparent exposure to TDI and MDI.

A deficit for all cause mortality was seen in the cohort. The mortality was lowest during the first 10 years since the start of exposure, and the deficit became smaller with longer follow up periods. This is in accordance with previous observations ${ }^{11} 12$ and is ascribed to a healthy worker effect-that is, healthy people are more likely to gain employment. ${ }^{11}$

No excess risk for death from bronchial obstructive diseases was found (two deaths $v 3.3$ expected), but due to the low expected number, the confidence interval was extremely wide. It has been questioned whether the general population, which we have used, is a suitable reference group for this diagnosis. Järvholm et al have shown that the SIR for non-malignant respiratory diseases is $25 \%$ lower for gainfully employed men as compared to the general Swedish population. ${ }^{13}$

Table 7 Cancer incidence 1959-87 for selected sites in 4154 subjects employed for at least one year by time since first exposure

\begin{tabular}{|c|c|c|c|c|c|c|c|c|c|}
\hline \multirow[b]{3}{*}{ Tumour } & \multirow[b]{3}{*}{$I C D-7$} & \multicolumn{8}{|c|}{ Year since first exposure } \\
\hline & & \multicolumn{4}{|c|}{$1-10$} & \multicolumn{4}{|c|}{$>10$} \\
\hline & & $O$ & $E$ & $S I R$ & $(95 \% C I)$ & $O$ & $E$ & $S I R$ & $(95 \% C I)$ \\
\hline $\begin{array}{l}\text { Rectum } \\
\text { Lung } \\
\text { Lymphomas, myelomas } \\
\text { Non-Hodgkin's } \\
\text { lymphoma }\end{array}$ & $\begin{array}{l}154 \\
162-164 \\
200-203 \\
200,202\end{array}$ & $\begin{array}{l}2 \\
2 \\
0 \\
0\end{array}$ & $\begin{array}{l}1 \cdot 5 \\
3 \cdot 3 \\
2 \cdot 3 \\
1 \cdot 2\end{array}$ & $\begin{array}{l}1 \cdot 30 \\
0 \cdot 60 \\
0 \cdot 00 \\
0 \cdot 00\end{array}$ & $\begin{array}{l}(0 \cdot 16-4 \cdot 70) \\
(0 \cdot 07-2 \cdot 17) \\
(0 \cdot 00-1 \cdot 59) \\
(0 \cdot 00-3 \cdot 10)\end{array}$ & $\begin{array}{l}4 \\
2 \\
6 \\
4\end{array}$ & $\begin{array}{l}2 \cdot 1 \\
4 \cdot 6 \\
2 \cdot 4 \\
1 \cdot 4\end{array}$ & $\begin{array}{l}1 \cdot 92 \\
0 \cdot 44 \\
2 \cdot 49 \\
2 \cdot 80\end{array}$ & $\begin{array}{l}(0.52-4.92) \\
(0.05-1.58) \\
(0.91-5 \cdot 42) \\
(0.76-7 \cdot 16)\end{array}$ \\
\hline All & $140-209$ & 32 & $40 \cdot 9$ & $0 \cdot 78$ & $(0 \cdot 54-1 \cdot 12)$ & 40 & $48 \cdot 6$ & 0.82 & $(0 \cdot 59-1 \cdot 13)$ \\
\hline
\end{tabular}

Table 8 Cancer incidence 1959-87 for selected sites in 4154 subjects employed for at least one year by exposure to TDI or MDI in the workplaces

\begin{tabular}{|c|c|c|c|c|c|c|c|c|c|}
\hline \multirow[b]{3}{*}{ Tumour } & \multirow[b]{3}{*}{$I C D-7$} & \multicolumn{8}{|c|}{ Exposure to TDI or MDI in the workplaces } \\
\hline & & \multicolumn{4}{|c|}{ No exposure } & \multicolumn{4}{|c|}{ Apparent exposure } \\
\hline & & $O$ & $E$ & $S I R$ & $(95 \% C I)$ & $O$ & $E$ & $S I R$ & $(95 \% C I)$ \\
\hline $\begin{array}{l}\text { Rectum } \\
\text { Lung } \\
\text { Non-Hodgkin's lymphoma }\end{array}$ & $\begin{array}{l}154 \\
162-164 \\
200,202\end{array}$ & $\begin{array}{l}1 \\
3 \\
1\end{array}$ & $\begin{array}{l}1 \cdot 4 \\
3 \cdot 1 \\
1 \cdot 0\end{array}$ & $\begin{array}{l}1 \cdot 70 \\
0 \cdot 98 \\
1 \cdot 01\end{array}$ & $\begin{array}{l}(0.02-3 \cdot 90) \\
(0 \cdot 20-2 \cdot 86) \\
(0 \cdot 03-5 \cdot 63)\end{array}$ & $\begin{array}{l}5 \\
0 \\
2\end{array}$ & $\begin{array}{l}1 \cdot 8 \\
4 \cdot 0 \\
1 \cdot 4\end{array}$ & $\begin{array}{l}2 \cdot 73 \\
0 \cdot 00 \\
1 \cdot 45\end{array}$ & $\begin{array}{l}(0 \cdot 89-6 \cdot 38) \\
(0 \cdot 00-0 \cdot 92) \\
(0 \cdot 18-5 \cdot 24)\end{array}$ \\
\hline All & $140-209$ & 29 & $36 \cdot 7$ & 0.79 & $(0 \cdot 54-1 \cdot 14)$ & 39 & $45 \cdot 8$ & $0 \cdot 85$ & $(0 \cdot 61-1 \cdot 17)$ \\
\hline
\end{tabular}


TDI had been used in all plants and MDI in all but one (table 1). This made it impossible to separately evaluate the effects of exposure to these substances. It is reasonable to assume that the average airborne concentrations of TDI would be higher than for MDI, due to their difference in vapour pressure. This suggestion is supported by available measurements of isocyanates in air (table 1). It should, however, be noted that airborne exposure to MDI has not always been negligible (at least three times the present Swedish threshold limit value has been monitored). In many work tasks there has also been dermal contact with isocyanates, or with uncured polyurethane. Also there are reports of many accidental exposures to isocyanates due to spills and leakages. It is difficult to estimate the dermal uptake of TDI and MDI. There is, however, reason to believe that the concentrations in air correlate well with the degree of dermal contact. The dermal uptake may have been of greater importance for MDI than for TDI due to the mentioned differences in vapour pressure.

The exposure levels for TDI and MDI have varied considerably both between different workplaces in the plants and within them. The information derived from the company records on the work place and job tasks for the subject in the cohort has not always been specific. This has probably caused misclassification of exposure. The quality of these exposure data have not been affected by the health outcome for the subjects in the cohort. Thus the misclassification of exposure has been non-differential, and has not affected the validity of the study. On the other hand, non-differential exposure misclassification will of course decrease the precision and thereby the possibility of detecting a low or moderate true risk excess.

As a means of minimising misclassification of exposure, a case-referent study within the cohort will be performed, allowing a more detailed and precise exposure assessment.

The manufacture of polyurethane foam has caused exposure not only to isocyanates but also to other chemicals. Regrettably these other chemicals have only been monitored rarely. The accelerator MOCA, which may be absorbed dermally as well as by inhalation, is carcinogenic in animals. ${ }^{14}$ The use of MOCA has, however, only been reported from one of the plants $(\mathrm{G})$.

It is well known that secondary amines may be nitrosated to carcinogenic $N$-nitrosamines, endogenously ${ }^{15}$ as well as in the work environment. ${ }^{16}$ Only primary and tertiary amines have been used in the polyurethane foaming process, however, and these substances will not form nitrosamines. On the other hand, secondary amines have been detected as impurities in commercial grades of tertiary amines. ${ }^{17}$ Moreover, the possibility of dealkylation of tertiary amines cannot be ruled out. Thus the risk of substantial exposure to secondary amines in the polyurethane foam manufacturing industry is probably low, but cannot be totally neglected.

The substances used in polyurethane manufacture as expanding agents, lubricants, accelerators, and organic solvents have varied between the plants. The exposure to isocyanates is thus the only common chemical characteristic of the plants.

The overall incidence of cancer was low in the cohort, probably a reflection of the healthy worker effect. Occupational exposure to aromatic amines has mainly been associated with bladder cancer, ${ }^{18}$ but there was no tendency for such excess of risk in the present cohort. Two tumour diagnoses, rectal cancer and non-Hodgkin's lymphoma, were, however, in excess, although not significantly. This may be due to chance. On the other hand, as the risk estimates increased with both a 10 year induction latency period before the start of observation and with apparent exposure to TDI and MDI, a true association cannot be ruled out. Non-Hodgkin's lymphoma has previously been associated with occupational exposure to organic solvents, ${ }^{19} 20$ fenoxy acids, and chlorophenols, ${ }^{20-22}$ and various insecticides. ${ }^{23}$ Data on aetiological factors for rectal cancer are both sparse and contradictory. In many previous epidemiological studies rectal cancers have been lumped together with colon cancer, despite their different aetiological causes. Colon cancer is associated with nutritional factors such as lack of dietary fibres and high fat intake ${ }^{24}$ and sedentary jobs. ${ }^{25}$ Rectal cancer in young men has been associated with jobs in which dusts or fumes were inhaled. ${ }^{26}$ Further, excess rectal cancer has been found in metal workers, ${ }^{27-29}$ including workers grinding stainless steel. ${ }^{30}$

It must be considered that the cohort is still young and little time has elapsed since the start of exposure, shown by the fact that only $4.5 \%$ of the cohort had died during the observation period. The possibility for a full evaluation of the long term health effects of exposure was thus limited. Future follow up will be more fruitful, but it will still take some time before a low or moderate excess risk will be conclusively evaluated. A further five year follow up of the cohort will, with $80 \%$ statistical power and $p \leqslant 0.05$, enable the evaluation of a relative risk of $\geqslant 2.5$ for rectal cancer and $\geqslant 2.8$ for nonHodgkin's lymphoma. The corresponding risk figures for a further 10 year follow up are $\geqslant 2.2$ and $\geqslant 2 \cdot 4$ respectively.

Ms C Paradis and Ms M Wikman are gratefully acknowledged for their valuable technical assistance. Representatives from the companies, company health services, the labour inspectorate, $\mathrm{Mr}$ Anders Holmén, M Eng and Mr Bengt Åkesson, 
Dr Med Sci, are gratefully acknowledged for their generous assistance in providing valuable information. The project was supported by grants from the Swedish Work Environment Fund and the Medical Faculty at the University of Lund.

1 Gilbert DS. Fate of TDI and MDI in air, soil and water. Fournal of Cellular Plastics 1988;24:178-92.

2 Andersen $M$, Binderup $M-L$, Kiel $P$, Larsen $H$, Maxild J. Mutagenic action of isocyanates used in the production of polyurethanes. Scand $\mathcal{f}$ Work Environ Health 1980;6:221-6.

3 World Health Organisation. Environmental health criteria 75. Toluene diisocyanates. Geneva: WHO, 1987.

4 National Toxicology Program. Toxicology and carcinogenesis studies of commercial grade 2,4(80\%)- and 2,6(20\%)-toluene diisocyanate (CAS No. 26471-62-5) in F344/N rats and B6C3F1 mice (gavage studies). Research Triangle Park, North Carolina: US National Toxicology Program 1986. (Technical Report No 251, NIH Publ No 86-2507.)

5 Loeser E. Long-term toxicity and carcinogenicity studies with $2,4 / 2,6$-toluene-diisocyanate $(80 / 20)$ in rats and mice. Toxicol Lett 1983;15:71-81.

6 International Agency for Research on Cancer. IARC monographs on the evaluation of the carcinogenic risk of chemicals to humans - some chemicals used in plastics and elastomers. Vol 39. Lyon:IARC, 1986.

7 US National Institute for Occupational Safety and Health. Criteria for a recommended standard occupational exposure to diisocyanates. Rockville, Maryland:NIOSH, 1978.

8 Brorson T, Skarping G, Sangö C. Biological monitoring of isocyanates and related amines IV. 2,4- and 2,6- toluenediamine in hydrolysed plasma after testchamber exposure of humans to 2,4- 2,6-toluene diisocyanate. Int Arch Occup Environ Health 1991;63:253-9.

9 Hagmar L, Nielsen J, Skerfving S. Clinical features and epidemiology of occupational respiratory disease caused by small molecular weight organic chemicals. Monogr Allergy 1987;21:42-58

10 Peters JM, Murphy RLH, Pagnotto L, Whittenberger JL. Respiratory impairment in workers exposed to "safe" levels of toluene diisocyanate (TDI). Br f Ind Med 1970;20: $364-7$.

11 Fox AJ, Collier FF. Low mortality rates in industrial cohort studies due to selection for work and survival in the industry. British fournal of Preventive and Social Medicine 1976;30:225-30.

12 Pearce NE, Checkoway $\mathrm{H}$, Shy $\mathrm{CH}$. Time related factors as potential confounders and effect modifiers in studies based on an occupational cohort. Scand $\mathcal{f}$ Work Environ Health 1986;12:97-107.

13 Järvholm B, Hörte LG, Larsson S, Thorén K. Respiratory mortality-an underestimated occupational risk? In: C
Hogstedt, C Reuterwall, eds. Progress in occupational epidemiology. Reuterwall: Excerpta Medica, 1988;281-3.

14 Ward E, Smith AB, Halperin W. 4,4'-Methylenbis (2Chloraniline): an unregulated carcinogen. $A m$ f Ind Med 1987;12:537-49.

15 Rounbehler DP, Fajen JM. N-Nitroso compounds in the factory environment. Cincinnati: US Department of Health and Human Services 1983, ppl-204. (USDHHS (NIOSH) Publ No. 83-114.)

16 Bellander T, Österdahl B-G, Hagmar L, Skerfving S. Excretion of $N$-mononitrosopiperazine in urine in workers manufacturing piperazine. Int Arch Occup Environ Health 1988;60:25-9.

17 Brorson T, Sangö C, Skarping G, Renman L. Evaluation of chromatographic methods for the determination of isocyanates in air. International fournal of Environmental and Analytical Chemistry. 1990;38:399-413.

18 Clayson DB. Occupational bladder cancer. Prev Med 1976; $5: 228-44$.

19 Olsson H, Brandt L. Supradiaphragmatic presentation of non-Hodgkin's lymphoma in men occupationally exposed to organic solvents. Acta Med Scand 1981;210:415-8.

20 Persson B, Dahlander A-M, Fredriksson $M$, Noorlind Brage $\mathrm{H}$, Ohlson $\mathrm{C}-\mathrm{G}$, Axelson $\mathrm{O}$. Malignant lymphomas and occupational exposures. Br f Ind Med 1989;46:516-20.

21 Hardell L, Eriksson M, Lenner P, Lundgren E. Malignant lymphoma and exposure to chemicals, especially organic solvents, chlorophenols and phenoxy acids: a case-control study. Br F Cancer 1981;43:169-76.

22 Hoar SK, Blair A, Holmes FF, et al. Agricultural herbicide use and risk of lymphoma and soft tissue sarcoma. $\mathcal{F} A M A$ 1986;256:1141-7.

23 Cantor KP, Blair A, Everett G, et al. Pesticides and other agricultural risk factors for non-Hodgkin's lymphoma among men in lowa and Minnesota. Cancer Res 1992;52:2447-55.

24 Weisburger $\mathrm{JH}$, Wynder EL, Horn CL. Nutritional factors and etiologic mechanisms in the causation of gastrointestinal cancers. Cancer 1982;50:2541-9.

25 Garabrant DH, Peters JM, Mack TM, Bernstein L. Job activity and colon cancer risk. Am $\mathcal{F}$ Epidemiol 1984;119: 1005-14.

26 Peters RK, Garabrant DH, Yu MC, Mack TM. A casecontrol study of occupational and dietary factors in colorectal cancer in young men by subsite. Cancer Res 1989;49:5459-68.

27 Gallagher RP, Threllfall WJ. Cancer mortality in metal workers. Can Med Assoc F 1983;129:1191-4

28 Vena J, Sultz HA, Fiedler RC, et al. Mortality of workers in an automobile engine and parts manufacturing complex. $\mathrm{Br} f$ Ind Med 1985;42:85-93.

29 Park RM, Wegman DH, Silverstein MA. Causes of death among workers in a bearing manufacturing plant. Am $\mathcal{F}$ Ind Med 1988;13:569-80.

30 Svensson BG, Englander V, Åkesson B, Attewell R, Skerfving $S$, Möller $T$. Deaths and tumours among workers grinding stainless steel. Am f Ind Med 1989;15:51-9.

Accepted 10 August 1992 